\title{
The Flower of Service Concept on Business Restaurant- A Case Study of Meat Lovers Restaurant Yogyakarta, Indonesia
}

\author{
Indriyani Yalika Liem, Dessy Isfianadewi
}

\begin{abstract}
A business with excellence in service quality will improve customer satisfaction. Service is a core product that provides basic consumer benefits. With the appropriate supplementary services, the value of an existing product core can be increased.The study aims to analyze the implementation of the Flower of Service concept in the all-you-can-eat restaurant "Meat Lovers Yogyakarta" in Indonesia.The method used was observation to see the development of Meat Lovers Yogyakarta as a new restaurant in implementing the concept of TFOS in its business services.The results of this study revealed that the number of supplement service elements does not guaranty the superiority of a company. However, the appropriate additional services that complement the core products make the company superior. Thus, a company is required to make plans for conformance to core products and supplementary services according to the company's capabilities and customer needs to create a competitive advantage..
\end{abstract}

Index Terms - Flower of Service, TFOS, BusinessModel ,Service, Restaurant.

\section{INTRODUCTION}

Nowadays, the culinary business, especially restaurants, is growing rapidly. It creates a higher level of competition in the culinary business. The successful restaurant business can be measured through the service concept, taste, and the advantages of each restaurant. Thus, having good business and marketing strategy is necessary for maintaining the existence of a product.

The restaurant is a commercial business that provides food and beverage services to the public and is managed professionally (Soekresno,2000). A restaurant or cafe offers food and service. Hence, customers do not only expect food delicacy but also service meetings when they eat (Ramanathan, 2015). Many restaurants offer advantages in addition to a distinctive cuisine, such as the complete and appropriate service concept and facilities. The complete and appropriate service concept and facilities aim to increase the attractiveness compared to its competitors.

Service quality is usually based on customer judgment regarding the overall excellence of the services provided (Qin, 2009). The visitors will feel comfortable with the satisfying service from the restaurant. Visitors will revisit the restaurant since the restaurant does not only provide good food but also has a cozy feeling.

Indriyani YalikaLiem, Master of Management Program, Universitas Islam Indonesia, Yogyakarta, Indonesia

Dessy Isfianadewi, Department of Management, Universitas Islam Indonesia, Yogyakarta, Indonesia
Each service company will always encounter the demand to provide the appropriate service products in accordance with customer expectations. In other words, the company should and develop service products. The implementation of The Flower of Service concept in a restaurant is an appropriate form of planning in developing service-based business concepts in newly established restaurants.

The Flower of Service concept was first introduced by Christopher Lovelock. According to this concept, value is built on core products and supplementary services. This concept categorizes supplementary services into facilitating and improving additional services. Supplementary services that ease the service process or help in the use of core products are needed. The services are information, order receipt, billing, and payment. Supplementary services that add value to customers include consultation, hospitality, luggage, and handling exceptions. The Flower of Service analogy helps us understand the need for consistent performance on all additional elements. Thus, the weaknesses in one element do not damage the overall impression.

\section{LITERATUR REVIEW}

\section{A. Marketing Services}

Service is where customers or consumers can benefit from the expected service value. The concept of marketing services is an attempt to bring together products or services produced by a company with prospective customers who will use these services, hence, products and services produced must be able to meet customer needs and desires (Lovelock \&Gummesson, 2011)

\section{B. Service Quality}

Quality is the totality of features and characteristics of a product or service that is related to its ability to satisfy customer implied needs (Kotler\& Keller, 2016). Service quality is the level of excellence expected and control over the level of excellence to meet customer desires.

According to Parasuraman in Tjiptono and Chandra (2011), factors that affect the quality of service are expected service and perceived service. If the service received is appropriate and meets what is expected, then the service is said to be good or positive. If the perceived service exceeds the expected service, the service quality is perceived as ideal. Conversely, if perceived service is worse than expected service, then the quality of service is perceived as negative or poor. Therefore, the quality of service depends on the ability of the company and workers to consistently 
meet customer expectations.

\section{The Flower of Service}

The Flower of Service is a service concept that describes the main product of a service company added by supplementary services depicted in the form of the flower where despite the good company's core product; if the supplementary services provided are not good, the whole will be not beautiful (Lovelock \&Wirtz, 2012).

\section{The Flower of Service}

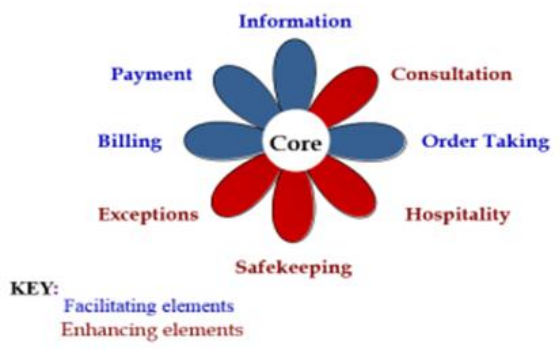

Flower of Service is divided into eight elements. The first is facilities that contain four elements, namely information, payment, billing, and order taking. Second is the enhancing group, namely consultation, hospitality, safe keeping / care taking and exceptions (Lovelock, 2011) :

1) Facilitating services or as a convenience element is a service to support the company's core services, how the main services are provided to customers :

a) Information refers to in order to get the desired value of a product/service offered, customers need to know relevant information of the product/ service, the information provided must be timely and accurate.

b) Order taking is when a customer is ready to buy, then the process of receiving the order must be done politely, quickly, accurately and precisely hindering the customer to feel spending unnecessary time and effort to obtain the services.

c) Billing in which the company gives bills to customers in a prompt and timely manner, explaining the total bill and the value accurately. Some billing systems are periodic billing, direct billing, verbal billing, machine billing, and selfbilling.

d) Payment refers to after giving the bill, the customer will immediately pay. That is why sometimes this becomes one with the billing petals. Cashless payment is supported by today's technological advancement.

2) Enhancing services is a reinforcing element that can increase added value to customers:

a) Consultation by giving advice to customer questions. Suggestions must be in accordance with current conditions.

b) Hospitality is how companies accept new customers with gratitude and greet old customers when they revisit. Some elements of hospitality are welcoming, eating and drinking, toilets, and other public facilities that can increase the value of its main facilities.

c) Safekeeping is the security that the customer wants when using the product/service.

d) Exceptions are things that occur outside the company's routine, such as special customer requests, complaints, and problem-solving that may occur during the service delivery process.

\section{RESEARCH METHODS}

The data used were the primary data. The data collection methods used were observation by making observations and recording the behavior of the object. It was carried out directly at the location of the object of research.

The object of research is a restaurant that was just established in 2019 in Yogyakarta, Indonesia.

The study focuses on knowing the extent to which the concept of the Flower of Service has been implemented at the Meat Lovers Restaurant, Yogyakarta.

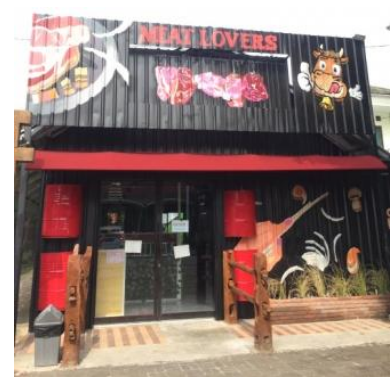

\section{RESULT}

The results of the study revealed that the Meat Lovers Restaurant has applied concept of Flower of Service in its service standards. The concept of Flower of Service from Meat Lovers Restaurant is explained as follows:

1) The element of facilitating services or as a form of convenience supplementary services are divided into four elements:

a) Information.To get the full value of the products/services, the customer needs to know the relevant information about the product/service. At this stage, Meat Lovers Restaurant makes it easy for customers to access restaurant information such as:

- Business location. Meat Lovers has registered locations on Google Maps to make it easy for customers to find its location.

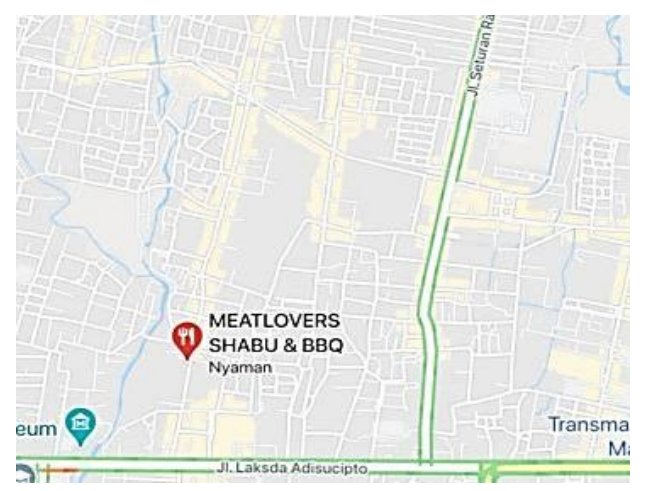


- The information on price, operating hours, terms and conditions, and the latest promotions can be accessed directly on the company's social media such as Instagram account @meatloversyogyakarta. On Instagram, the information provided is always updated and easily accessed freely by anyone who visits the account. The Instagram account also displays the menus and images and videos of the products.

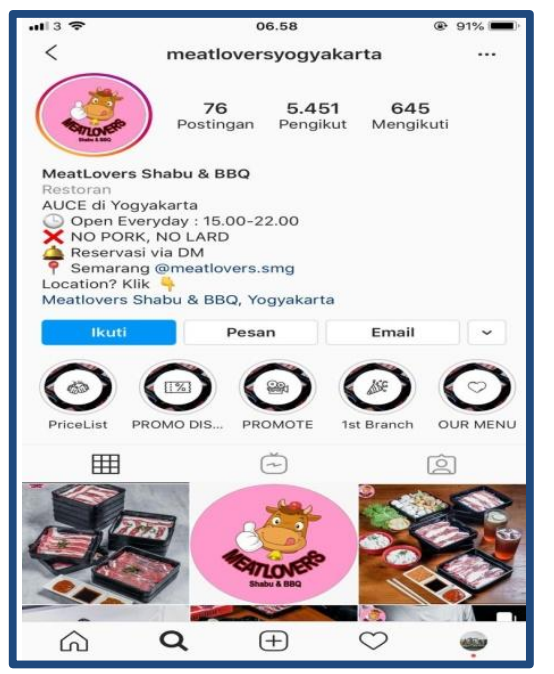

- The public facilities available are parking lots, $\mathrm{Wi}-\mathrm{Fi}$, and prayer rooms. When customers come to the restaurant there will be directions to the mosque and information of free Wi-Fi access that can be directly seen when customers choose the menu in front of the cashier's desk.

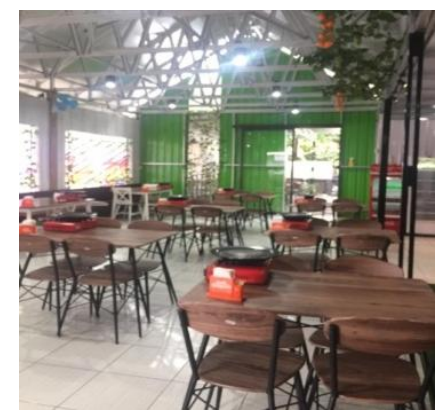

b) Order receipt.The order receipt must be done politely, quickly, accurately, and precisely as expected so the customers do not feel spending unnecessary time and effort to obtain the company's services. In Meat Lovers Restaurant, when customers arrive and choose the serving method, the ML team immediately welcomes and delivers customers to their prepared seats. Then, waiters provide a pan/grill along with other cooking utensils on the table and offer the customers whether they want to take their own food or being assisted. It aims to help customers who need help or difficulty in taking the menu. Meat Lovers also provides a way to order via the hotline or WhatsApp for customers who want to make a reservation beforehand. c) Billing. Giving bills to customers is done precisely, according to nominal spent. The billing method used by Meat Lovers cashier is that a customer comes and selects a menu, the total bill is immediately charged. The cashier will explain in detail about the orders, the total bill, with an accurate value. The bill is proceeded through a tablet using the MOKA application. This application is a paid cashier application that is useful to calculate the total customer bills and income each day. The risk of miscalculating becomes smaller. Billing is done early before the customer enters the dining area and immediately continues the payment process.

d) Payment. Given the bill, the customer will immediately pay. Thus, sometimes it becomes one with the billing petals. The current technology supports customers to pay cashless. To facilitate payment, Meat Lovers provides an EDC machine for non-cash payments, and payments can be made through OVO directly connected by the cashier application tablet.

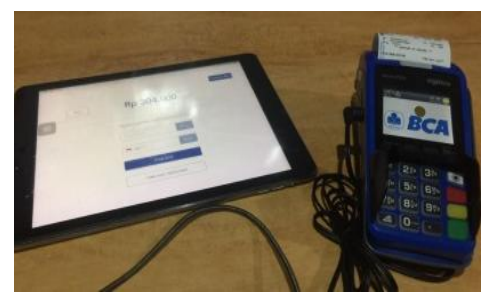

2) Enhancing services as a strengthening element that can increase added value to customers:

a) Consultation. Implemented by Meat Lovers Restaurant is by opening a service hotline and Whatsapp chat provided to customers if there are obstacles or complaints as well as suggestions to be conveyed directly to the restaurant. The Instagram account also displays videos and photos of the product as well as comments that are freely accessed by customers for question and answer that is responded quickly by the account admin.

b) Hospitality elements are hospitality services, warm welcome, food and drinks, clean and fragrant toilets, and other public facilities that can increase the value of hospitality to build better interactions with consumers. Meat Lovers provide facilities for places of worship such as a clean mosque. To create a warm and comfortable atmosphere, when customers enter the restaurant, all Meat Lovers employees simultaneously welcome them by shouting the phrase "SelamatDatang (welcome)" to gain positive respect from the customers.

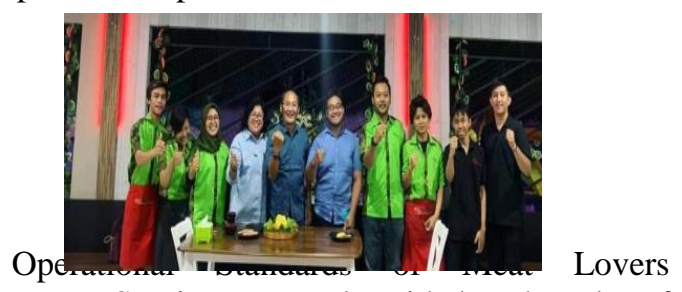

Restaurant Service are made with benchmarks of service quality, namely: 
- Reliability that all staff with the concept of customer focus provide an appropriate and correct method according to the type of service chosen by the customer, the method of shabu or $\mathrm{BBQ}$, and preparing equipment on demand.

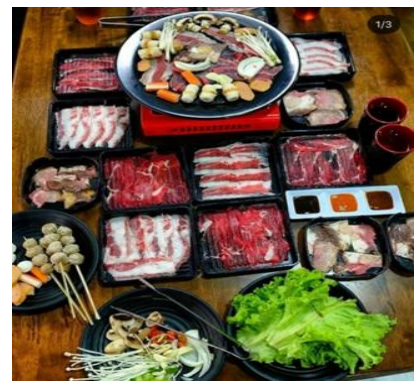

- $\quad$ Responsive that all staff must have awareness and act swiftly and deftly in helping customers who need help to take menus, fill empty stock material, and provide services on time.

- Certainty/guarantee that all staff must have knowledge and courtesy as well as confidence in providing genuine service to increase customer satisfaction and bring respect from the customer's point of view.

- Empathy. Meat Lovers staff must be able to pay special attention to customers. Empathy is the willingness of staff to approach customers, provide protection from difficulty in turning on or using the stove provided, and must be sensitive to the guests' feelings. The staff is not reluctant to apologize for the inconvenience.

- Access capability that every employee must establish eye contact with customers to build a closer quality relationship.

- Meat Lovers staff are also required to have the courtesy, respect all customers without exception and interacting, and contacting customers with friendliness.

- Staff must be able to communicate and convey information in easily understood language.

- Ensuring customer safety from the risk when using products and cooking equipment provided

- All Meat Lovers employees must prioritize the restaurant's physical appearance including:

- Staffs are asked to look neat and fragrant to maintain customer convenience.

- Maintain clean and hygienic equipment.

- Ensure that all equipment and supporting facilities are functioning properly etc.

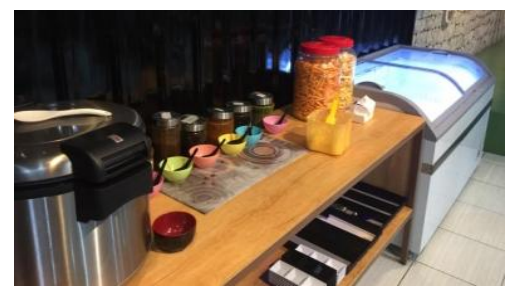

Finally, Meat Lovers Restaurant also display farm green house-themed concept with a 3D cow image wallpaper specifically used as a selfie spot for customers who want to take photos with a cow background as if it is a real cow. It is expected that customers can increasingly enjoy the concept of eating that is different from other restaurants.

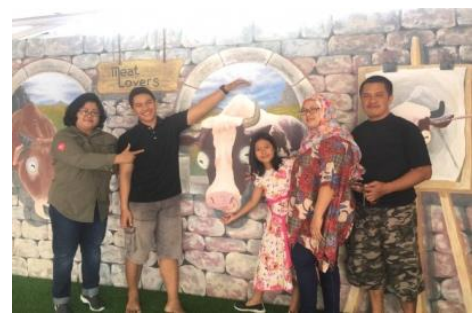

c) Safekeeping is the security that the customer wants when using the product/service. As for the customers' safekeeping, the item is kept at the cashier's desk with every corner of the restaurant installed with CCTV to monitor all operational activities and its safety. Customer safety has been maximized by the use of dining tables with heat and fire-resistant coatings. This also minimize the risk of wildfire. The parking facilities at the restaurant are fairly narrow so that when the number of customers exceeds the capacity of the parking lot, some customers choose to go elsewhere.

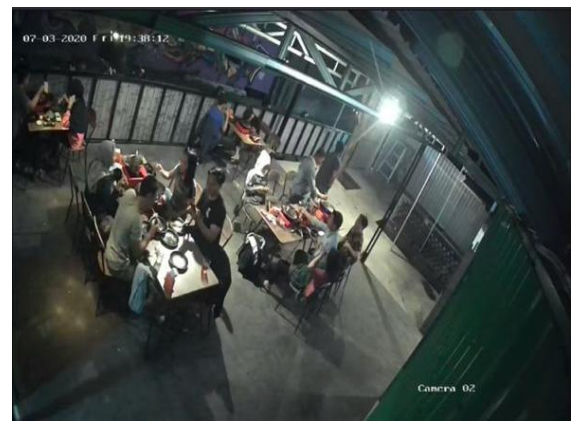

d) Exceptions are things that occur outside the company's routine, such as special customer requests, complaints, and problem-solving that may occur while the service delivery occurs. Some exceptions are special requests, for example, related to religious rituals or diffability, the damaged serving equipment, or the difficulty in using the product. The employees have been equipped with more knowledge to fulfill the needs of customers in anticipating sudden events. Exceptions in restaurants are run out of gas, the broken stove, or customers give suggestions of the less appealing menus so that management can revise the existing menu.

\section{DISCUSSION}

The eight supplementary service categories that make up the "Flower of Service" collectively provide many options for enhancing the core products in the company's service concept. The eight elements are mutually reinforcing and can produce a neatly arranged service concept. Meat Lovers Yogyakartaas a newly established restaurant has applied 
the concept of Flower of Service to design its restaurant service concept.

The properly-implemented convenience services such as information and reservations allow customers to use core products more effectively such as information on directions to service locations, operating hours, price, and information on how to use core products/supplementary services.

Furthermore, an order receipt must be done politely, quickly, accurately, and precisely as expected to hinder the customer to feel spending unnecessary time and effort to obtain the services. Supported by adequate internet applications, it is easier for customers and employees to process orders and place reservations. Billing should be done timely, accurate, readable, and informative so that customers do not have trouble reading the bills. Billing can be done through self-billing, saying it verbally to the customer, or from a billing application that makes the calculations easier. Finally, it is necessary to provide noncash payment facilities such as debit payment, payments through the OVO application, or other online payments. Companies will be benefited from non-cash payment since it reduces the cash and minimizes the risk of counterfeit and underpaid money.

The reinforcing elements can be adapted to the convenience elements. Starting with a consultation that provides a simple response to customer questions about the information obtained which involves dialogue and tailors solution and suggestions to probe customer requirements as part of theconsultation.

The hospitality element is showing excitement when meeting new customers and warmly welcoming old customers. Giving a greeting and saying the name if you already recognize them will give satisfaction to the customers. Friendliness and attention to customers both face to face and via phone must be done with good interaction. Operational standards for service needs to be made using the hospitality element for employee behavior. The elements of politeness, empathy, responsiveness, and communication are the benchmarks of the hospitality dimension.

For the save keeping element, some customers might need help with save keeping. Providing save keeping services for goods, helmet, or coat can be the supplementary service that can provide more satisfaction for customers. The secure and convenient parking is also a determining factor for a large number of customers coming. The lack of parking space will make some customers choose to go elsewhere. In this case, the company must ensure the security and safety of save keeping element in company.

. The last one is the exception element. The company management must be able to provide solutions and anticipation for each specific request from the customers such as the damage and so on. A smart business must be able to anticipate exceptions and make plans and directions for unexpected circumstances.

\section{CONCLUSION}

The restaurant business is the business that is most in demand. However, the risk of failure is also high. There are many causes of failure, one of them is not paying attention to the service to the customer. Service is a major factor in increasing customer satisfaction. Every company or service business is demanded to provide appropriate service products according to customers expectations. Thus, the company needs to innovate in developing its service products.

In service marketing, there is the concept of The Flower of Service developed by Christopher Lovelock and JochenWirtz to help business owners better understand the products offered to customers. Implementing the concept of The Flower of Service in a restaurant is an appropriate form of planning in developing service concepts in a newly established company. The concept of Flower of Service can help companies to design service products that are appropriate and in accordance with customer needs to complement and add value to core products. A unique and different service concept from competitors making the company superior. It provides differentiation for each service provider such as restaurants, theaters, hotels, or other types of services.

This study concluded that the number of flower petals as the analog to the concept of The Flower of Service representing supplementary services do not make companies superior. However, appropriate and perfect flower petals supplementing core products will make the company become superior. Overall, a company is obliged to make plans to match supplementary services with the company's ability and customer needs to create a competitive advantage in the market.

\section{REFERENCES}

[1] Lovelock, Christopher, JochenWirtz\& Jacky Mussry. (2011) PemasaranJasa: Manusia, Teknologi, Strategi. Jilid 1 EdisiKetujuh. Jakarta: Erlangga.

[2] Lovelock, C., \&Gummesson. (2011). PemasaranJasa (Seventh ed.).Erlangga.

[3] Qin Hong and Victor R. Prybutok. (2009), "Service quality, customer satisfaction, and behavioral intentions in fast-food restaurants", International Journal of Quality and Service Sciences Vol. 1 No. 1, 2009 pp. 78-95.

[4] Ramanathan, R., Di, Y. \&Ramanathan, U. (2016), "Moderating roles of customer characteristics on the link between service factors and satisfaction in a buffet restaurant", Benchmarking: An International Journal, Vol. 23 No. 2, pp. 469-486. https://doi.org/10.1108/BIJ-012015-0012.

[5] Soekresno. (2000)Manajemen Food and Beverage. Edisike II. Jakarta:PT. GramediaPustakaUtama

[6] Tjiptono, Fandy\&Gregorius Chandra. (2011). Service, Quality and Satisfaction (ed 3). Yogyakarta: Andi.

[7] Zhang,Z\&Law,R.(2013), "Regional effects on customer satisfaction with restaurants', International Journal of Contemporary Hospitality Management Vol. 25 No. 5, pp. 705-722. 